\title{
Analisis Kualitas Website Terhadap Kepuasan Penggunaan Elarning Universitas Bina Darma Sebagai Pembelajaran Di Masa Pandemi Covid 19 Menggunakan Metode WEBQUAL 4.0
}

\author{
Sisca Monita \& Ilman Zuhri Yadi \\ Fakultas Teknik Ilmu Komputer, Universitas Bina Darma \\ Email: Monitasisca100@gmail.com
}

\begin{abstract}
E-learning is an electronic distance learning system that uses network and computer technology. There are many models of using e-learning, one of which is the use of e-learning at Bina Darma University during the COVID-19 pandemic, where more use of e-learning and online learning systems during the pandemic period, for this reason the quality of e-learning services can be measured using Webqual. Webqual is a method used to measure website quality based on end users. Webqual is structured in research on 3 dimensions, namely Usability, information, and service interaction. This study aims to determine the quality of the e-learning website of Bina Darma University as student learning taken by 101 students and to find out the most influential indicators in the quality of e-learning. If the alpha value is greater than the $\mathrm{R}$ table, then the consistency of the R table is declared valid. On the Likert test scale, it is known that the usability dimension or indicator gets the highest usability level, so the usability dimension has a positive effect on user satisfaction.
\end{abstract}

Keywords : Analisis, Webqual 4,0 Universitas, Elearning, Mahasiswa

\section{Pendahuluan}

Penggunaan teknologi informasi dan pemanfaatan intermet dizaman yang semakin canggih ini sangat luas.pada masa sekarang hampir seluruh Perguruan tinggi menggunakan Website Elearning sebagai salah satu pelayanan kepada seluruh civitas kampus tersebut.

Universitas Bina Darma merupakan salah Satu Universitas Swasta yang populer di sumatera selatan. Universitas Bina Darma mempunyai Website Elearning yang bergerak dalam berbagai bidang yang membantu kegiatan operasional dan salah satunya Website Elarning dengan situs elearning.binadarma.ac.id sesuai dengan namanya Website ini digunakan untuk kegiatan pembelajaran Mahasiswa dalam kuliah Online khususnya saat daring dimasa Covid 19 ini.

Penelitian Ini mengambil Studi Kasus Elearning Universitas Bina Darma karena Website Tersebut Belum Pernah diukur sebelumnya dan juga Bertujuan Untuk mengukur kualitas Website. Pengukuran Kualitas Website yang dilakukan Berdasarkan Sudut Pandang kepuasan Pengguna (user satisfaction) agar dapat memanfaatankan Website secara Optimal.Oleh karena itu Diperlukan Analisis Tentang Faktor apa saja yang mempengaruhi tingkat kualitas dalam penggunaanya. Hasil dari analisis tersebut dapat menentulan Faktor Faktor yang berpengaruh untul meningkatkan Website Dilihat Dari kepuasan Pengguna. Salah satu metode yang Dapat Digunakan Adalah dengan menggunakan Metode Webqual 4.0.

Webqual merupakan salah satu metode dengan teknik pengukuran kualitas website berdasarkan persepeksi pengguna. Webqual sudah mulai dikembangkan sejak tahun 1998 
dan telah mengalami beberapa interaksi dalam mnyusun pertanyaan.

Masalah yang Dibahas Dalam Kualitas penggunaan Elearning pada Pembelajaran Universitas Bina Darma pada masa Covid 19 adalah apakah Elearning sebagai Pembelajaran Mahasiswa memberi kemudahan Mahasiswa dan berpengarun signifikan Khususnya Pembelajaran Berbasis Online seperti sekarang apakah kualitas Informasi berpengaruh signifikan terhadap kepuasan penggunaan Pada Pembelajaran Elearning, dan kualitas Interaksi berpengaruh signifikan Terhadap kepuasan penggunaan pada Website Elearning Universitas.

Berdasarkan uraian permasalahan diatas, menjadi latar belakang bagi penulis untuk melakukan suatu penelitian Universitas Bina Darma maka dengan ini mengangkat judul "Analisis kualitas Website terhadap kepuasan penggunaan elarnning Universitas Bina Darma sebagai Pembelajaran dimasa Pandemi Covid menggunakan metode Webqual 4.0"

\section{Tinjauan Literatur}

\subsection{Kualitas}

Kualitas didefinisikan sebagai suatu penyajian produk atau jasa sesuai ukuran yang berlaku di tempat produk tersebut diadakan dan penyampaian yang setidaknya bisa sama dengan yang diinginkan dan diharapkan oleh konsumen, kualitas disebut baik jika penyedia jasa memberikan pelayanan yang setara dengan yang diharapkan oleh pelanggan yang diinginkan konsep kualitas didasarkan pada ciri ciri kualitas yang seharusnya konsisten satu sama lainnya.

kualitas merupakan standard yang harus dicapai oleh instisusi atau bisnis yang berkembang untuk memenuhi tuntutan dalam penggunaanya. Sehingga kepuasan pengguna yang terdapat dalam website Univetsitas Bina Darma pada masa pandemi Covid 19 juga memenuhi standard dan kepuasan dalam pelayanan website Universitas Bina Darma Sudah benar benar baik dan sempurna yang dilakukan secara kinerja yang professional yang menggunakan penggunaan yang baik (Prasastono and Pradapa 2012).

\subsection{Kualitas Website}

Website adalah kumpulan informasi baik berupa teks, naskah, gambar diam atau gerak, animasi ataupun suara,dan atau gabungan dari semuanya yang bersifat statistik maupun dinamis yang membentuk satu rangkaian sistem yang saling berkaitan, dimana masingmasing akan memudahkan pelanggan mendapat kesimpulan tentang fitur dan benefit suatu produk. bisnis dengan situs online menjadi marak karena memudahkan untuk mendapatkan informasi pada produk yang diinginkan Kualitas website adalah suatu taktik atau metode pengukuran berdasar atas pendapat orang yang menggunakannya (Permana 2020).

\subsection{Website Elearning Universitas Bina Darma}

Website terdiri dari 3 jenis

\section{Website Statis}

Pada website statis untuk melakukan perubahan pada suatu halaman dilakukan secara manual dengan mengedit kode yang menjadi terstruktur website tersebut, karena website tersebut terstruktur pada Website elearnig.

2. Website Dinamis 
Pada Website dinamis disediakan halaman backend untuk mengedit konten Website dapat diakses oleh user. Contoh Website dimanis adalah web portal atau sehingga dapat di update, dan web berita yang memiliki fasilitas polling dan update berita

\section{Website Interaktif}

Pada Website interaktif user dapat berinteraksi dengan user lain, sebagai contoh adalah blog dan forum. Website terdiri dari page atau halaman, dan kumpulan halaman yang dinamakan

\section{Homepage}

Homepage berada pada posisi teratas, dengan halaman-halaman terkait berada di bawahnya yang disebut child page, yang berisi hyperlink ke halaman lain dalam web.

Pada pengertian 4 website diatas dapat disimpuljab adalah Website vergun untuk melakukan kegiatan terkait dengan halaman dinamika atau portal web begitupun dengan Website elearning Universitas Bina Darma Website yang berfungsi menjadi dan mencari informasi kepada mahasiswa dalam mengerjakan tugas dan latihan (Salamah et al. 2020).

\subsection{Kepuasan Pengguna}

Sebagai wadah informasi untuk para mahasiswa, dosen maupun masyarakat luas. Pelayanan Website tentunya didukung dengan banyak fitur sebagai informasi seperti data mahasiswa, kegiatan akademi pembayaran, nilai, bahkan layanan akademik kemahasiwaan. Layanan Akademik di bagian kemahasiswaan dari bagian informasi pelayanan dalam kepuasan penggunaan Website Universitas Bina Darma dimana ekspektasi penggunaan sangat bergantung pada karakteristik pribadi pada kebutuhan individu.

\subsection{Populasi}

Populasi merupakan wilayah generalisasi yang terdiri atas objek atau subjek yang mempunya kualitas dan karakteristik tertentu yang diterapkan oleh peneliti untuk dipelajari dan kemudian ditarik kesimpulannya Berdasarkan definisi diatas, maka populasi dalam penelitian ini adalah mahasiswa Universitas Bina Darma yang seluruhnya berjumlah 3619 orang dan diambil menjadi 101 orang mahasiswa menggunakan rumus slovin (Nadhifah and Kurniasih 2021).

\subsection{Sampel Penelitian}

Untuk menentukan ukuran sampel maka dapat menggunakan rumus Slovin dengan persentase Margin of error yang ditetapkan adalah 10\% jumlah sampel dibagi dan ditambahkan menjadi 2 untuk hasil pertama merupakan hasil yang didapat menjadi 603,166 responden sehingga memakan waktu lama untuk mengumpulkan kuisoner mahasiswa.oleh karena itu kembali dibulatkan menjadi 100,6,66 dan jika dihitung kembali menjadi 101.

$n=1+N(e)_{2}$

Keterangan :

$\mathrm{n} \quad=$ Ukuran sampel

$\mathrm{N}=$ Ukuran populasi 
e $\quad=$ Persen kesalahan pengambilan sampel (10\%) (Agung, 2012)

$\mathrm{n} \quad=3619 /\left(1+\left(3619 \times 0,10^{2}\right)\right)$

$\mathrm{n} \quad=3619 /(1+5)$

$\mathrm{n} \quad=3619 / 6$

$\mathrm{n} \quad=603,166$

Jika dibulatkan menjadi 604 responden.

$$
\begin{array}{ll}
\mathrm{n} & \left.=\frac{604}{1}+\left(604 \times 0,10^{2}\right)\right) \\
\mathrm{n} & =604 /(1+5) \\
\mathrm{n} & =604 / 6 \\
\mathrm{n} & =100,6,66 \text { responden jika dibulatkan menjadi } 101 \text { responden }
\end{array}
$$

(Sani 2021)

\subsection{Validitas dan Reabilitas}

Untuk melihat validitas usability quality dapat dilihat pada kolom corrected item total correlation. Jika nilai corrected item total correlation lebih beasr dari $r$ tabel maka pernyataan-pernyataan tersebut dapat dikatakan valid dengan menggunakan rumus product moment/pearson berikut ini

$$
r_{x y} \frac{\sum n X Y-\sum X \sum Y}{\sqrt{\left(n \sum x \sum^{2}-\left(\sum X\right)^{2}\right)\left(n \sum Y^{2}-\left(\sum Y\right)^{2}\right)}}
$$

Keterangan

$r_{x y} \quad=$ Koefesien korelasi

$\mathrm{X} \quad=$ Skor item butir

$\mathrm{Y}=$ Jumlah total skor tiap soal

$\mathrm{n} \quad=$ Jumlah responden

Untuk menguji keberartian koefesien $r_{x y}$ valid atau tidaknya dilakukan uji t, yang dilakukan dengan membandingkan antara $t_{\text {hitung }}$ dengan $t_{\text {tabel }}$ :

$\mathrm{t} \quad=\mathrm{r} \sqrt{n-2}$

$$
\text { ; dengan } \mathrm{db}=\mathrm{n}-2
$$

$$
\sqrt{1-r^{2}}
$$

Keterangan :

$\mathrm{r} \quad=$ Koefesien relasi hasil $\mathrm{r}$ hitung

$\mathrm{n} \quad=$ Jumlah responden 
Jika $t_{\text {hitung }}>t_{\text {tabel }}$ berarti valid jika $t_{\text {hitung }} \leq t_{\text {abel }}$ berarti tidak valid.

Reabilitas adalah suatu instrument yang cukup dapat dipercaya dan digunaikan untuk alat pengumpulan data karena instrument tersebut mengarahkan responden untuk menjawab bulir bulir pertanyaan yang digunakan alat untuk mengujii realibilitas adalah cronbach Alpha. Metode pengambilan keputusan biasanya menggunakan batasan 0,6 menurut sukaran (1992), reabilitas yang kurang dari 0,6 adalah reabilitas yang kurang baik,sedangkan 0,7 dapat diterima,dan diatas 0,8 adalah baik. Pengukuran validitas dan reabilitas dilakukan karena instrument yang valid rumus untuk menggunakan reabilitas yaitu :

$r_{1}=\left(\frac{n}{n-1}\right)\left(1-\frac{\sum_{s 1} 2}{\sum_{s 1} 2}\right)$

Keterangan

$r_{i} \quad=$ Reabilitas instrument

$\mathrm{n} \quad=$ Jumlah butir pertanyaan

$s_{1}^{2} \quad=$ Varians butir

$s_{t}^{2} \quad=$ Varians total

Metode penelitian pada analisis kualitas Website Elearning Universitas Bina Darma pada masa covid 19 menggunakan metode Webqual. Jenis Penelitian ini menggunakan penelitian survey, penelitian survey adalah penelitian yang mengambil sampel secara langsung dari populasi dan penelitian ini merupakan penelitian variabel dan merupakan fenomena yang terjadi,penelitian survei merupakan penelitian yang dilakukan pada objek dan kemudian dibagikan dari hasil survey.

Penelitian ini dilakukan di Universitas Bina Darma Palembang yaitu pada mahasiswa Universitas Bina Darma, penelitian ini dilakukan dari bulan 12021 sampai bulan 32021.

\section{Metode Penelitian}

\subsection{Jenis Penelitian}

Penelitian ini menggunakan penelitian survey, penelitian survey adalah penelitian yang mengambil sampel secara langsung dari populasi dan penelitian ini merupakan penelitian variabel dan merupakan fenomena yang terjadi,penelitian survei merupakan penelitian yang dilakukan pada objek dan kemudian dibagikan dari hasil survey.

\subsection{Lokasi Penelitian}

Penelitian ini dilakukan di Universitas Bina Darma Palembang yaitu pada mahasiswa Universitas Bina Darma, penelitian ini dilakukan dari bulan 12021 sampai bulan 32021.

\subsection{Populasi dan Sampel Penelitian}

\subsubsection{Populasi Penelitian}

Populasi penelitian ini adalah pengguna Website Elearning Bina Darma yaitu Mahasiswa Bina Darma. Berikut tabel penelitian dapat dilihat Pada tabel 3.1.

Tabel 3.1 Pengguna Website Elearning Bina Darma 


\begin{tabular}{|c|c|c|c|}
\hline No & Jurusan & Angkatan & $\begin{array}{c}\text { Jumlah } \\
\text { Populasi }\end{array}$ \\
\hline 1 & Ilmu computer & $2014-2020$ & 39 \\
\hline 2 & Ekonomi dan bisins & $2014-2020$ & 74 \\
\hline 3 & Teknik & $2014-2020$ & 231 \\
\hline 4 & Ilmu komunikasi & $2014-2020$ & 931 \\
\hline 5 & Psikologi & $2014-2020$ & 828 \\
\hline 6 & Keguruan,ilmu pendidikan dan Bahasa & $2014-2020$ & 757 \\
\hline 7 & Program pasca sarjana & $2014-2020$ & 759 \\
\hline 8 & Vokasi & & 370 \\
\hline \multicolumn{3}{|c|}{ Total } & 3619 \\
\hline
\end{tabular}

\subsubsection{Sampel Penelitian dan Teknik Pengambilan Sampel}

Penentuan jumlah sampel menggunakan hasil populasi dari rumus slovin dengan proses kesalahan dari penarikan samoel sebesar $10 \%$ jumlah sampel yaitu mahasiswa populasi diambil menggunakan rumus slovin berikut :

$$
n=1+(e)_{2}
$$

Keterangan :

$$
\begin{array}{ll}
\mathrm{n} & =\text { Ukuran sampel } \\
\mathrm{N} & =\text { Ukuran populasi } \\
\mathrm{e} & =\text { Persen kesalahan pengambilan sampel (10\%) (Agung,2012) } \\
\mathrm{n} & =3619 /\left(1+\left(3619 \times 0,10^{2}\right)\right) \\
\mathrm{n} & =3619 /(1+5) \\
\mathrm{n} & =3619 / 6 \\
\mathrm{n} & =603,166
\end{array}
$$

Jika dibulatkan menjadi 604 responden.

$$
\begin{array}{ll}
\mathrm{n} & \left.=\frac{604}{1}+\left(604 \times 0,10^{2}\right)\right) \\
\mathrm{n} & =604 /(1+5) \\
\mathrm{n} & =604 / 6 \\
\mathrm{n} & =100,6,66 \text { responden jika dibulatkan menjadi } 101 \text { responden }
\end{array}
$$

Jadi berdasarkan rumus diatas dan nilai yang dimasukan maka jumlah sampel dalam 
penelitian ini ada 101 orang. Sehingga 101 dianggap sebagai variabel A.

Jumlah perhitungan sampel dapat disimpulkan berdasarkan tabel 3.2 berikut ini:

Tabel 3.2 Perhitungan Jumlah Sampel

\begin{tabular}{|c|l|c|c|}
\hline No & \multicolumn{1}{|c|}{ Jurusan } & $\begin{array}{c}\text { Jumlah } \\
\text { Populasi }\end{array}$ & $\begin{array}{c}\text { Jumlah } \\
\text { Sampel }\end{array}$ \\
\hline 1 & Ilmu Komputer & 1453 & 78 \\
\hline 2 & Ekonomi Dan Bisnis & 667 & 7 \\
\hline 3 & Teknik & 502 & 3 \\
\hline 4 & Ilmu Komunikasi & 180 & 6 \\
\hline 5 & Psikologi & 214 & 3 \\
\hline 6 & Keguruan Ilmu Pendidikan Dan Bahasa & 223 & 2 \\
\hline 7 & Program Pasca Sarjana & 0 & 0 \\
\hline 8 & Vokasi & 370 & 2 \\
\hline & Total & 3619 & 101 \\
\hline
\end{tabular}

Sumber : Universitas Bina Darma Palembang

\subsection{Jenis Data, Metode Instrumen dan Pengumpulan Data}

\subsubsection{Jenis Data}

Jenis data dalam penelitian ini adalah data kuantitatif yaitu data yang berbentuk angka, sumber yang diperlukan berasal dari :

1. Data Primer, yaitu data yang diperoleh langsung oleh responden melalui kuisoner yang dibagikan dari google form

2. Data skunder, yaitu data yang diperoleh dari dokumen, laporan uang dibuat oleh Universitas Bina Darma Palembang yang dibutuhkan oleh laporan ini adalaha mahasiswa Universitas Bina Darma Palembang.

\subsubsection{Metode Pengumpulan Data/Instrument Pengumpulan Data}

Pengumpulan data yang dilakukan dalam laporan ini diambil dengan mengggunakan gioogle form kemudian diisi oleh mahasiswa melalui google form tersebut kuisoner yang dibagikan yaitu kuisoner tertutup yaitu kuisoner yang dibagikan dalam bentuk sedemikian rupa sehingga responden diminta untuk memilih satu jawaban yang tepat dari skala 1 - 5 menggunakan skala linier penilaian diberikan dalam setiap jawaban dari pertanyaan kuisoner dalam penelitian sebagai berikut :

Tabel 3.3 Tabel Bobot Nilai Pertanyaan Responden 


\begin{tabular}{|c|c|}
\hline Jawaban & Nilai \\
\hline Sangat Setuju & 5 \\
\hline Setuju & 4 \\
\hline Tidak Berpendapat & 3 \\
\hline Tidak Setuju & 2 \\
\hline Sangat Tidak setuju & 1 \\
\hline
\end{tabular}

\subsection{Variabel Penelitian}

Variabel adalah apapun yang membedakan atau membawa variasi dalam suatu nilai. Variabel ini terdiri dari variabel terikat (dependent) adalah variabel yang menjadi perubahan sehingga timbulnya variabel terikat yang menjadi sebab akibat karena adanya Variabel bebas.

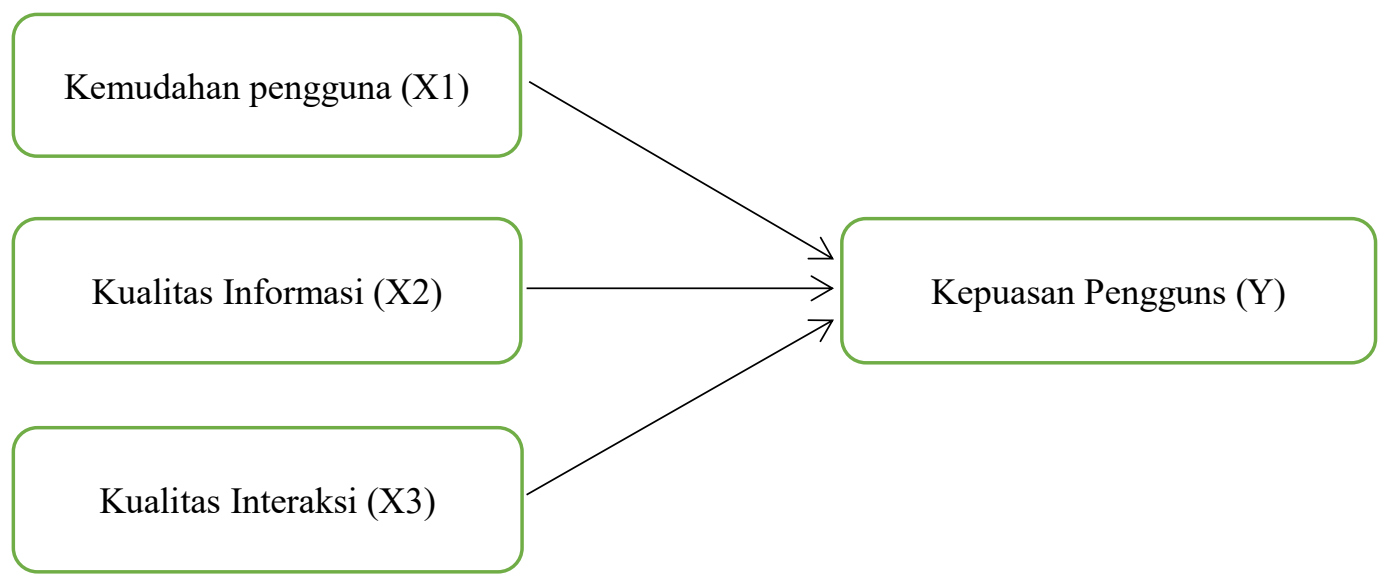

Gambar 3.1 Diagram jalur pada Webqual 4.0

Keterangan:

$\mathrm{X} 1=$ Variabel kemudahan (independent)

$\mathrm{X} 2=$ Variabel kualitas informasi (independent)

$\mathrm{X} 3=$ Variabel kualitas interaksi (independent)

$\mathrm{Y}=$ Variabel kepuasan pengguna (dependent)

\subsection{Menentukan Model Dan Hipotesis}

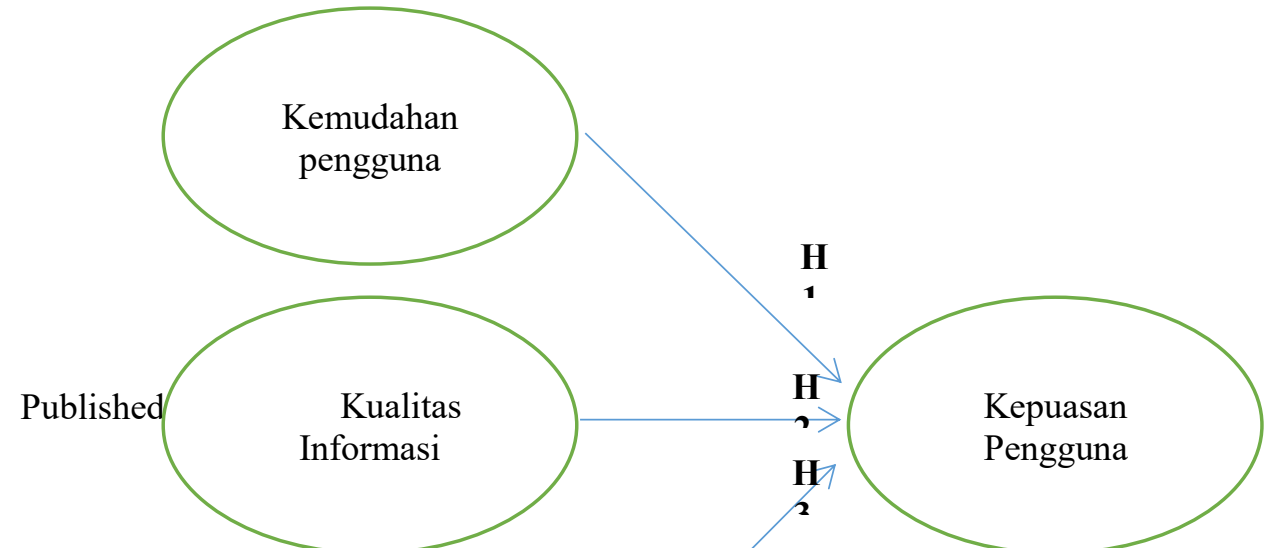


Gambar 3.2 Model Webqual 4.0

\section{Hasil dan Pembahasan}

\subsection{Gambaran Umum Objek Penelitian}

Website Elearning Universitas BIna Darma adalah Website yang digunakan untuk mengakses pembelajaran Mahasiswa atau mata kuliah yang berlangsung secara Online lewat Elearning. Website Elearning Bina Darma adalah pembelajaran mahasiswa dalam melaksanakan mata kuliah secara Elearning saat online, Website Elearning Bina Darma biasanya berisi Mata kuliah yang diambil oleh mahasiswa dan forum yang berbentuk forum diskusi bagi Mahasiswa dan dosen dan dapat diakses melalui link https://elearning.binadarma.ac.id/ sig in melalui nim dan password, dalam Pembelajaran dimasa Covid 19 ini pembelajaran sering digunakan dari Elearning karena jadwal tatap muka di tiadakan terlebih dahulu karena adanya wabah Covid 19 untuk sementatra mahasiswa yang awalnya belajar secara offline kemudian dialihkan secara Online terlebih dahulu dari bulan maret 2020 di Universitas Bina Darma Palembang.

\subsection{Gambaran Umum Responden}

Responden ini berasal dari pengguna Werbsite Elearning https://elearning.binadarma.ac.id/ yaitu Mahasiswa Universitas Bina Darma, sesuai dengan jumlah sampel yang digunakan adalah rumus Slovin,maka responden yang diminta untuk mengisi kuisoner adalah sebesar 101 responden.

Jumlah Persentase Responden Berdasarkan Fakultas

\begin{tabular}{|l|c|c|}
\hline \multicolumn{1}{|c|}{ Fakultas } & Jumlah & Persentase \\
\hline Ilmu komputer & 71 & $70,3 \%$ \\
\hline Ekonomi dan bisnis & 9 & $8,9 \%$ \\
\hline Teknik & 3 & $3 \%$ \\
\hline Ilmu komunikasi & 7 & $6,9 \%$ \\
\hline Psikologi & 3 & $3 \%$ \\
\hline
\end{tabular}




\begin{tabular}{|c|c|c|}
\hline $\begin{array}{l}\text { Keguruan dan pendidikan } \\
\text { bahasa }\end{array}$ & 4 & $4 \%$ \\
\hline Program pasca sarjana & 0 & $0 \%$ \\
\hline Vokasi & 4 & $4 \%$ \\
\hline Jumlah & 101 & $100.0 \%$ \\
\hline
\end{tabular}

Jumlah Persentase Responden Berdasarkan Semester

\begin{tabular}{|l|c|c|}
\hline \multicolumn{1}{|c|}{ Semester } & Jumlah & Persentase \\
\hline 2 & 5 & $5 \%$ \\
\hline 4 & 7 & $6,9 \%$ \\
\hline 6 & 33 & $32,7 \%$ \\
\hline 8 & 52 & $51,5 \%$ \\
\hline 9 & 1 & $1 \%$ \\
\hline Alumni 2018 & 1 & $1 \%$ \\
\hline Alumni & 1 & $1 \%$ \\
\hline $\begin{array}{l}\text { Alumni Univ Bidar } \\
\text { angkatan 2016 }\end{array}$ & $\mathbf{1 0 1}$ & $\mathbf{1 0 0 , 0 \%}$ \\
\hline Jumlah & $1 \%$ \\
\hline
\end{tabular}

Sumber : Data kuisoner yang diolah

Hasil Pengujian Hipotesis

Dalam uji hipotesis dalam penelitian ini dilakukan dengan ujian regresi linier berganda yang terdiri dari uji $\mathrm{T}$ dan uji $\mathrm{F}$ dengan menggunakan SPSS 16.0 uji f digunakan untuk menguji variable dependent sedangkan uji t digunakan untuk menguji pengaruh variable independent terhadap variable dependent.

1. Uji T (Secara Berganda)

Uji t bertujuan untuk mengetahui ada atau tidaknya pengaruh parsial yang diberikan oleh variable bebas $(\mathrm{X})$ berdasarkan hasil analisis yang peneliti lakukan seperti pada table berikut :

\section{Uji T}




\section{Coefficients $^{\mathrm{a}}$}

\begin{tabular}{|c|c|c|c|c|c|}
\hline \multirow[b]{2}{*}{ Model } & \multicolumn{2}{|c|}{$\begin{array}{l}\text { Unstandardized } \\
\text { Coefficients }\end{array}$} & \multirow{2}{*}{\begin{tabular}{|c|}
$\begin{array}{c}\text { Standardiz } \\
\text { ed } \\
\text { Coefficien } \\
\text { ts }\end{array}$ \\
\\
Beta
\end{tabular}} & \multirow[b]{2}{*}{$\mathrm{T}$} & \multirow[b]{2}{*}{ Sig. } \\
\hline & B & $\begin{array}{l}\text { Sta. } \\
\text { Error }\end{array}$ & & & \\
\hline $1 \quad$ (Constant) & -1.006 & .502 & & 2.003 & .048 \\
\hline $\begin{array}{l}\text { Usabillity } \\
\text { quallity } \\
\text { (X1) }\end{array}$ & .086 & . 020 & . 388 & 4.184 & . 000 \\
\hline $\begin{array}{l}\text { Information } \\
\text { quallity }(\mathrm{X} 2 \\
\text { ) }\end{array}$ & .032 & .026 & . 110 & 1.235 & .220 \\
\hline $\begin{array}{l}\text { Interaction } \\
\text { quallity (X3 } \\
\text { ) }\end{array}$ & .155 & .035 & .362 & 4.383 & . 000 \\
\hline
\end{tabular}

a. Dependent Variable: User Stastfication(Y)

a. Pengujian Hipotesis Pertama (H1)

Diketahui nilai signifikasi nilai X1 terhadap Y sebesar $0,00<0,05$ dan nilai $t_{\text {hitung }}$ $4.184>\mathrm{t}$ table 1,984 , sehingga dapat disimpulkan hasil $\mathrm{H} 1$ dapat diterima yang berarti berpengaruh $\mathrm{X} 1$ terhadap $\mathrm{Y}$.

b. Pengujian Hipotesis Kedua $(\mathrm{H} 2)$

Diketau nilai signifikasi untuk pengaruh X2 terhadap Y sebesar $0,220<0,05$ dan nilai $t_{\text {hitung }} 1.235>$ tabel 1,984 sehingga dapat disimpulkan hasil $\mathrm{H} 2$ tidak dapat diterima yang berarti tidak berpengaruh $\mathrm{X} 2$ terhadap $\mathrm{Y}$

c. Pengujian Hipotesis Ketiga (H3)

Diketahui nilah signifikasi untuk pengaruh X3 terhadap Y sebesar $000<0,05$ dan nilai hitung $t_{\text {hitung }} 4.383>$ tabel 1.984 ,sehingga dapat disimpulkan bahwa hasil $\mathrm{H} 1$ dapat diterima dan berpengaruh X3 terhadap Y.

\section{Uji F}

Uji $f$ bertujuan untuk mengetahui ada atau tdaknya pengaruh bersama sama yang diberikan variabel bebas $(\mathrm{X})$ terhadap variabel terikat $(\mathrm{Y})$ hasil uji $\mathrm{F}$ akan menjelaskan hasil $F_{\text {hitung }}$ dan $F_{\text {Tabel }}$, hasil yang didapat adalah sebagai berikut :

hasil uji F 
ANOVA $^{b}$

\begin{tabular}{|c|c|c|c|c|c|}
\hline Model & $\begin{array}{l}\text { Sum of } \\
\text { Squares }\end{array}$ & $\mathrm{df}$ & $\begin{array}{l}\text { Mean } \\
\text { Square }\end{array}$ & $\mathrm{F}$ & Sig. \\
\hline $\begin{array}{ll}1 & \text { Regressio } \\
& \mathrm{n}\end{array}$ & 40.869 & 3 & 13.623 & $\begin{array}{r}34.64 \\
6\end{array}$ & $.000^{\mathrm{a}}$ \\
\hline Residual & 38.141 & 97 & .393 & & \\
\hline Total & 79.010 & 100 & & & \\
\hline
\end{tabular}

a. Predictors: (Constant), X3, X2, $\mathrm{X} 1$

b. Dependent Variable: Y

Untuk menentukan $F_{\text {Tabel }}$, maka digunakan persamaan sebagi berikut:

Keterangan :

$\mathrm{k} \quad=$ Jumlah variabel

$\mathrm{n} \quad=$ Jumlah responden

$F_{\text {Tabel }}=\mathrm{f}(\mathrm{k} ; \mathrm{n}-\mathrm{k})$

$=\mathrm{f}(3 ; 101-3)$

$=\mathrm{f}(3 ; 98)$

Maka F tabel sebesar 2,70

Berdasarkan hasil yang didapat maka dapat diketahui dari nilai signifikasi untuk pengaruh $\mathrm{X} 1, \mathrm{X} 2$, dan X3 secara bersama sama terhadap Y sebesar $0,000<0,05$ dan nilai $F_{\text {hitung }}$ $34.646>F_{\text {Tabel }} 2,70$ sehingga dapat disimpulkan bahwa $\mathrm{H} 4$ diterima yang berarti tidak dapat pengaruh X1, X2, X3, secara bersama sama terhadap Y

\section{Uji F}

Model Summary

\begin{tabular}{|l|l|r|r|r|}
\hline $\begin{array}{l}\text { Mode } \\
\mathbf{l}\end{array}$ & \multicolumn{1}{|c|}{$\mathbf{R}$} & $\begin{array}{c}\text { R } \\
\text { Square }\end{array}$ & \multicolumn{1}{c|}{$\begin{array}{c}\text { Adjusted R } \\
\text { Square }\end{array}$} & $\begin{array}{c}\text { Std. Error of the } \\
\text { Estimate }\end{array}$ \\
\hline 1 & $.719^{\mathrm{a}}$ & .517 & .502 & .62706 \\
\hline
\end{tabular}

a. Predictors: (Constant), X3, X2, X1

Berdasarkan output diatas dapat diketahui jumlah R square adalah 0,517 sehingga dapat 
disimpulkan bahwa pengaruh X1, X2, X3 secara bersamaan terhadap Y adalah 51,7\% sedangkam sisanya 48,3\% dipengaruhi oleh variabel independent X1, X2, X3.

Pembahasan

Berdasarkan hasil dari kuisoner yang telah disebar dan diolah oleh peneliti menggunakan SPSS 16.0 menunjukan bahwa ke 4 variabel dari usability, information qualllity, interaction quality dan user stastfication maka menghasilkan angka kepuasan pengguna kualitas Website.

Dari analisis deskriptif yang telah dilakukan oleh peneliti maka dalam variabel usability quality Variabel X1. menghasilkan skor rata rata mean dari X1.1 adalah 4.20 median 4.00 Mode 4 dan total penilaian 425.00 sedangkan nilai rata rata dari variabel X1.2 mean 4.09 median 4.00 mode 4.00 dan total penilaian 414.00 di variabel X1.3 mean 3.74 median 4.00 dan mode 5.00 sedangkan hasilnya 378.00 dan divariabel X1.4 nilai mean 4.31 median 4.00 dan mode 5.00 jadi total keseluruhannnya adalah 436.00 di variabel X1.5 mean 1.17 median 4.00 mode 4.00 dan hasilnya adalah 422.00 di variabel X1.6 nilai mean 4.09 median 4.00 mode 4.00 dan hasilnya adakah 380.00 dan di variabel X1.7 hasil mean 3.76 median 4.00 mode 4.00 dan hasilnya adalah 380.00 .

Selanjutnya dari tabel information quality variabel X2.1 menghasilkan skor rata rata mean 4.06 median 4.00 mode 4.00 jadi hasil yang didapat adalah 4.11 .00 di variabel X2.2 nilai mean 4.03 median 4.00 mode 4.00 dan hasilnya adalah 408.00 di variabel X2.3 mean 4.03 median 4.00 mode 4.00 dan hassil yang didapat 408.00 berdasarkan variabel X2.4 mean 3.92 median 4.00 dan mode 4.00 dan hasil yang didapat adalah 408. Dan divariabel X2.5 nilai mean yang didapat 4.06 median 4.00 mode 5.00 dan hasil yang didapat 411.00 .

Selanjutnya divariabel interaction quality variabel X3.1 mean 3,79 median 4.00 mode 4.00 dan hasil yang didapat adalah 383.00 di variabel X3.2 mean 4.029 median 4.00 dan mode 4.00 dan hasil yang didapat adalah 407.00 kemudian divariabel X3.3 mean 4.17 median 4.00 dan mode 4.00 dan hasil yang didapat adalah 4.22.

Selanjutnya pada variabel User stastfication terdapat 1 variabel dengan mean 3.90 median 4.00 dan mode 4.00 kemudian hasil yang didapat adalah 394.00.

Dapat diketahui dari ke 4 variabel diatas dari Website Elearmimg Universitas Bina Darma dimasa pandemi Covid 19 maka dapat disimpulkan bahwa Website ini cukup berkualitas menurut kepuasan pengguna dilihat dari 4 variabel yang diolah tidak memerlukan banyak perbaikan menurut hasil yang didapat ini maka Website sudah cukup berkualitas dimata penggunanya dan sudah cukup memenuhi kepenuhan pengguna.

\section{Kesimpulan}

Berdasarkan hasil penelitian yang didapat maka dapat disimpulkan tentang Analisis kualitas Website terhadap kepuasan penggunaan elarnning Universitas Bina Darma sebagai Pembelajaran dimasa Pandemi Covid menggunakan metode Webqual 4.0 maka peneliti memberikan kesimpulan :

1. Kualitas Website maka dapat disimpulkan Usabillity Quallity (X1) pengguna Website Elearning Universitas Bina Darma pada masa covid 19 memilih setuju dan puas pada Website sangat jelas digunakan saat berinteraksi dengan pengguna.

2. Kualitas dari variabel maka dapat disimpulkan Information Quallity (X2) pengguna Websit Elearning Universitas Bina Darma pada masa covid 19 memilih Setuju atau puas pada pertanyaan Website Elearning Universitas Bina Darma mempunyai Informasi Yang Akurat dan terkini saat mengakses Mata Kuliah. Website Elearning Universitas Bina Darma pada masa covid 19 memilih sangat Setuju Bertambahnya 
Link aplikasi Zoom,Google Meets di Elearning Universitas Bina Darma pada masa covid 19 menyebabkan pengguna merasa kurang menguasai materi saat dosen menjelaskan.

3. Kualitas dari variabel maka dapat disimpulkan Interaction Quallity (X3) pengguna Website Elearning Universitas Bina Darma pada masa covid 19 memilih Setuju atau puas dengan pernyataan Website Elearning Universitas Bina Darma memberikan ruang diskusi forum antara dosen dan mahasiswa.

4. Kualitas dari variabel maka dapat disimpulkan User Stastification (Y) pengguna Website Elearning Universitas Bina Darma pada masa covid 19 memilih Setuju atau puas dengan pertanyaan Website Elearning Universitas Bina Darma pada masa Pandemi Covid 19 mempunyai reputasi baik dalam penggunaan Website.

5. Berdasrkan hasil yang didapat maka keseluruhan diatas maka kepuasan pengguna teerhadap Website Elearning Universitas Bina Darma dimasa pandemi Covid 19 ini sudah baik dan memuaskan penggunanya

\section{Referensi}

Antoni, D., Herdiansyah, M. I., Akbar, M., \& Sumitro, A. (2021). Pengembangan Infrastruktur Jaringan Untuk Meningkatkan Pelayanan Publik di Kota Palembang. JURNAL MEDIA INFORMATIKA BUDIDARMA, 5(4), 1652-1659.

Antoni, D., Jie, F., \& Abareshi, A. (2020). Critical factors in information technology capability for enhancing firm's environmental performance: case of Indonesian ICT sector. International Journal of Agile Systems and Management, 13(2), 159-181.

Antoni, D., \& Akbar, M. (2019). E-supply chain management value concept for the palm oil industry. Jurnal Sistem Informasi, 15(2), 15-29.

Antoni, D., Fikari, D., \& Akbar, M. (2018). The readiness of palm oil industry in enterprise resource planning. Telkomnika, 16(6), 2692-2702.

Fauzi, F., Dencik, A. B., \& Asiati, D. I. (2019). Metodologi Penelitian untuk manajemen dan akuntansi. Jakarta: Salemba Empat.

Nadhifah, Lailatun, and Dedeh Kurniasih. 2021. "THE INFLUENCE OF WORK DISCIPLINE AND WORK SUPERVISION ON EMPLOYEE PERFORMANCE AT PUTRI DUYUNG ANYER HOTEL IN SERANG BANTEN.” Sakti 1(1).

Permana, Ade Indra. 2020. "Pengaruh Kualitas Website, Kualitas Pelayanan, Dan Kepercayaan Pelanggan Terhadap Minat Beli Pelanggan Di Situs Belanja Online Bukalapak.” Jurnal Ekonomi dan Bisnis 25(2).

Prasastono, Ndaru, and Sri Yulianto Fajar Pradapa. 2012. "Kualitas Produk Dan Kualitas Pelayanan Terhadap Kepuasan Konsumen Kentucky Fried Chicken Semarang Candi." Jurnal Ilmiah Dinamika Kepariwisataan 11(2).

Salamah, Irma, Lindawati Lindawati, Muhammad Fadhli, and R D Kusumanto. 2020. "EVALUASI PENGUKURAN WEBSITE LEARNING MANAGEMENT SYSTEM POLSRI DENGAN METODE WEBQUAL 4.0.” Jurnal Digit 10(1): 1-10.

\section{Copyrights}

Copyright for this article is retained by the author(s), with first publication rights granted to the journal. 
This is an open-access article distributed under the terms and conditions of the Creative Commons Attribution license (http://creativecommons.org/licenses/by/4.0/) 